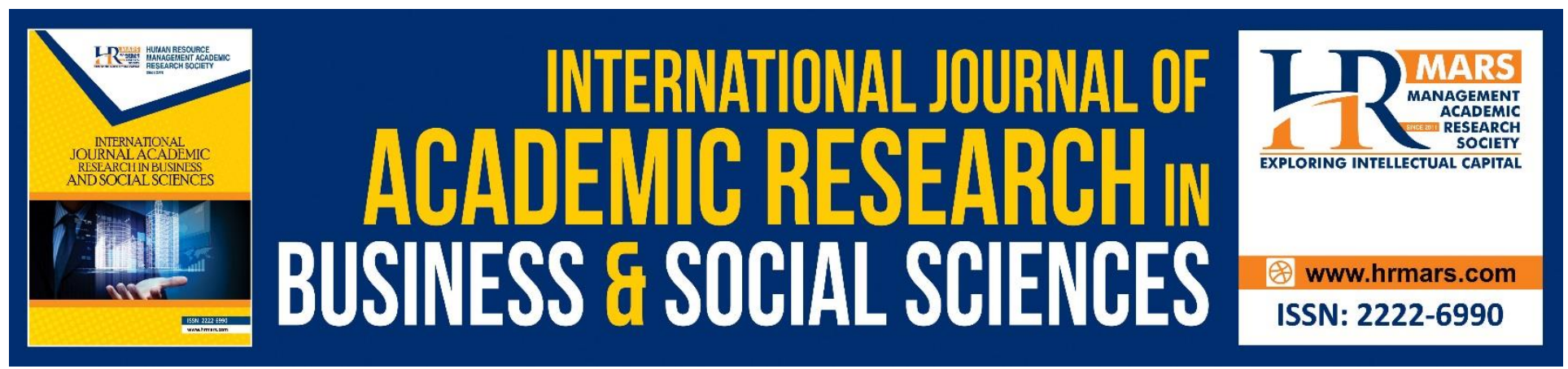

\title{
Learning Accounting Courses on Digital Platforms: How Do Non-Accounting Students Accept?
}

Farhana Hasbolah, Fadhilah Md Nor, Fatin Nabilah Kamarudzaman, Siti Aisyah Omar

To Link this Article: http://dx.doi.org/10.6007/IJARBSS/v10-i8/7541

DOI:10.6007/IJARBSS/v10-i8/7541

Received: 08 May 2020, Revised: 04 June 2020, Accepted: 20 July 2020

Published Online: 16 August 2020

In-Text Citation: (Hasbolah, Nor, Kamarudzaman, \& Omar, 2020)

To Cite this Article: Hasbolah, F., Nor, F. M., Kamarudzaman, F. N., \& Omar, S. A. (2020). Learning Accounting Courses on Digital Platforms: How Do Non-Accounting Students Accept. International Journal of Academic Research in Business and Social Sciences. 10(8), 318-332.

Copyright: (C) 2020 The Author(s)

Published by Human Resource Management Academic Research Society (www.hrmars.com)

This article is published under the Creative Commons Attribution (CC BY 4.0) license. Anyone may reproduce, distribute, translate and create derivative works of this article (for both commercial and non-commercial purposes), subject to full attribution to the original publication and authors. The full terms of this license may be seen

at: http://creativecommons.org/licences/by/4.0/legalcode

Vol. 10, No. 8, 2020, Pg. 318 - 332

http://hrmars.com/index.php/pages/detail/IJARBSS

JOURNAL HOMEPAGE

Full Terms \& Conditions of access and use can be found at http://hrmars.com/index.php/pages/detail/publication-ethics 


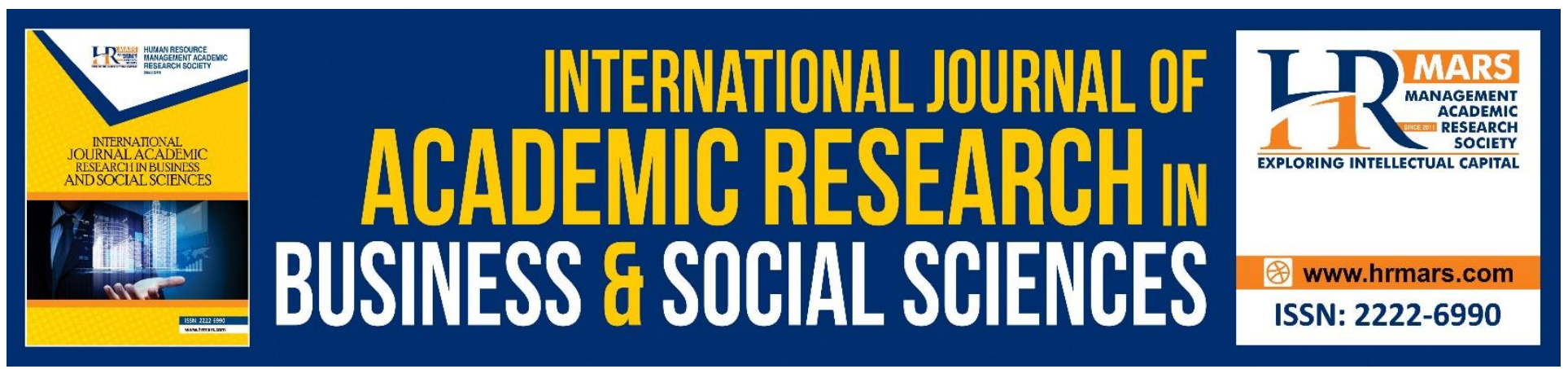

\title{
Learning Accounting Courses on Digital Platforms: How Do Non-Accounting Students Accept?
}

\section{Farhana Hasbolah, Fadhilah Md Nor, Fatin Nabilah Kamarudzaman, Siti Aisyah Omar}

Faculty of Business and Accountancy, Universiti Selangor (UNISEL), Shah Alam, Malaysia

Email: farhana.hasbolah@unisel.edu.my

\begin{abstract}
The study aimed to examine the perception and the factors influencing the online learning process of non-accounting students in accounting courses. A quantitative approach with a structured questionnaire was used for data collection and it was distributed to the non-accounting undergraduate students who enrolled in two accounting courses; Principles of Accounting and Managerial Accounting in the semester April 2020. The questionnaire consists of four dimensions; learner characteristics, technology and system, interactive application, and instructor characteristics. Of the total of 194 non-accounting undergraduate students, there were 130 respondents participated in the study. Descriptive statistics and statistical inference were accustomed analyse the mean, standard deviation, frequency, and percentage using the Statistical Package for Social Sciences version 25.0. The findings showed that there was a high-level acceptance of the non-accounting students towards learning accounting courses online. Results indicated that the instructor and learner characteristics were the two most significant influential factors of non-accounting students to learn accounting courses on digital platforms. The findings of this study cannot be generalised to other universities due to different environments and situations. Nevertheless, the implications of the study are crucial for instructors, practitioners, and institutions who are within the planning and are currently engaged in offering online learning courses.
\end{abstract}

Keywords: Acceptance, Accounting Course, Digital Platform, Non-Accounting Students, Online Learning

\section{Introduction}

The outbreak of the Covid-19 epidemic has affected various sectors including the education sectors. Many countries have called for the temporary closure of educational institutions as a part of measures to prevent the spread of the Covid-19 pandemic. On 16 March 2020, the Malaysian Prime Minister, Tan Sri Muhyiddin Yassin has announced on the closure of all kindergartens, government and private schools, and other primaries, secondary and pre-university institutions following the implementation of government's Movement Control Order (MCO). The temporary closure of the schools and universities was expected to cause massive disruption to teaching and learning activities. 
INTERNATIONAL JOURNAL OF ACADEMIC RESEARCH IN BUSINESS AND SOCIAL SCIENCES Vol. 10, No. 8, 2020, E-ISSN: 2222-6990 @ 2020 HRMARS

As a result, public and private universities have activated the online learning mode for classes and postponed outdoor activities.

The Malaysia Education Blueprint 2015-2025 has been introduced by the Ministry of Higher Education in 2015 to transform the higher education sector to be in line with the emergence of Industrial Revolution 4.0 (IR 4.0). One amongst the shifts discussed in the blueprint is to empower online learning, particularly to widen access to good quality content, enhance the standard of teaching and learning, and lower the cost of delivery (Ministry of Education Malaysia, 2013). Hence, the world crisis has provided the opportunities to revisit, revise, and rethink the present education system to adapt to the changes brought by digital technology and adopt a more flexible and interactive approach in teaching and learning activities. Thus, online learning is not any longer an option but a requirement to both instructors and learners, particularly during the enforcement of MCO. Many local universities, both public and private including schools in Malaysia, have no choice but to use virtual teaching and learning methods to confirm that the syllabus of teaching is best delivered and learning sessions are not delayed.

\section{Problem Statement}

With the development of modern technology, students are significantly in need of relevant knowledge, experience, and training to stay competitive in the real world after they graduated from their studies. Non-accounting students are sometimes required to complete certain accounting courses throughout their programme either as compulsory or elective courses. In the Faculty of Business and Accountancy, a faculty in a Malaysian university, students who are majoring in Business, Finance, Human Resource, and Marketing are required to enroll in two accounting courses, Principles of Accounting and Managerial Accounting during their first year of study. The first course contains a strong emphasis on general journal entries, ledger accounts, financial ratios, and simple preparation of the financial statement, while the latter cover job order costing, process costing, cost volume profit analysis, absorption and variable costing, and budgeting.

Accounting courses require an understanding of theoretical concepts and high practicality. It cannot be denied that certain topics are quite challenging for students. Previous studies have revealed that the non-accounting students perceived the accounting courses were irrelevant to their discipline, difficult to handle, and hard to score (Malgwi, 2006). As a consequence, many of them have lost focus and interest due to failed in grasping the concept of accounting. The non-accounting students needed a clear explanation and encouragement to increase their confidence and interest to enroll in accounting courses. Tickell, Tiong, and Balasinghan (2012) stated that it is difficult to develop the first course in accounting that is interesting, useful, and challenging to accounting and non-accounting students. Ismail and Kasim (2011) proposed that the accounting course, particularly Management Accounting should be offered to higher level non-accounting students rather than taking it within the earlier study. They found that year of study has a positive impact on the non-accounting students' academic performance of the accounting course.

Table 1 below shows the academic performance of the non-accounting students in the Faculty of Business and Accountancy who enrolled in the two accounting courses for the past six regular semesters. Each semester is conducted over 18 weeks comprise of weekly lectures, mid-semester 
INTERNATIONAL JOURNAL OF ACADEMIC RESEARCH IN BUSINESS AND SOCIAL SCIENCES Vol. 10, No. 8, 2020, E-ISSN: 2222-6990 @ 2020 HRMARS

break, revision week, and exam weeks. Based on the table, it can be seen that the non-accounting students were managed to score the Managerial Accounting course as compared to Principles of Accounting course. The course encompasses a $100 \%$ passing rate for three consecutive semesters. However, about 3.2 percent to 11.1 percent of the students have failed in Principles of Accounting course for the past six semesters. Salwa, Amariah Hanum, Haslin, Jamil, and Nurizzah (2013) revealed that various factors result in the high failure rate; the course was a non-preferred course to the nonaccounting students, the questions in the final exam were not clear, and there have been plenty of assignments for the semester.

Table 1: Exam Results for Accounting Courses per Academic Session

\begin{tabular}{lllllll}
\hline Academic Session & \multicolumn{3}{l}{ Principles of Accounting } & \multicolumn{3}{l}{ Managerial Accounting } \\
\cline { 2 - 7 } & $\begin{array}{l}\text { No of } \\
\text { Students }\end{array}$ & $\begin{array}{l}\text { Pass } \\
\text { (\%) }\end{array}$ & $\begin{array}{l}\text { Fail } \\
\text { (\%) }\end{array}$ & $\begin{array}{l}\text { No of } \\
\text { Students }\end{array}$ & $\begin{array}{l}\text { Pass } \\
(\%)\end{array}$ & $\begin{array}{l}\text { Fail } \\
\text { (\%) }\end{array}$ \\
\hline January 2017 & 57 & 96.5 & 3.5 & 4 & 100 & 0 \\
September 2017 & 243 & 88.9 & 11.1 & 23 & 78.3 & 21.7 \\
February 2018 & 88 & 89.8 & 10.2 & 33 & 84.8 & 15.2 \\
September 2018 & 284 & 96.8 & 3.2 & 120 & 100 & 0 \\
April 2019 & 103 & 90.3 & 9.7 & 78 & 100 & 0 \\
November 2019 & 219 & 93.6 & 6.4 & 200 & 100 & 0 \\
\hline
\end{tabular}

Common teaching methodology for these courses to include an explanation with theory, questioning, and discussion among students, problem-based learning, group learning-teamwork, and assessment over lecture materials like tests and quizzes. The course content and learning material are taught by the instructor to a group of students in the classroom. Many of the universities have provided the Learning Management System (LMS) as an online learning platform designed to facilitate the delivery of learning materials online. However, most of the lecturers used this online learning platform as a repository for students to obtain learning materials in the form of a "PowerPoint" presentation and notes in PDF format. The worldwide spread of Covid-19 has shown a sharp increase in the use of online learning to replace the teaching and learning activities in the classroom. Various platforms such as WhatsApp, Telegram, YouTube, Kahoot, Zoom, Skype, Google Meet, and other online web conferencing platforms are widely used to replace the traditional type of learning instruction.

With the advancement and development of technology information that exists today, the method of teaching has changed to suit the present needs. According to Amichai-Hamburger, Wainapel \& Fox (2002), students are more actively involved in the online discussions. Students can interact directly with the instructor if they have questions about the topics studied. There are four types of students' interactions as discussed by Said and Tahir (2013) which are between students and students, students and instructors, students and learning materials, and students and interfaces. However, Krishnan (2016) in his study found that students preferred and more comfortable interacting with their peers and the instructor in the face-to-face learning mode. Consistent with Tichavsky, Hunt, Driscoll, and Jicha (2015), students perceived online learning as lacking in social interaction with peers, and with the instructors. In other words, students do not feel that having online classes mode is akin to the lecture-based classroom. 
INTERNATIONAL JOURNAL OF ACADEMIC RESEARCH IN BUSINESS AND SOCIAL SCIENCES Vol. 10, No. 8, 2020, E-ISSN: 2222-6990 @ 2020 HRMARS

Hence, this study tries to examine if the preference for online learning could be predicted from some relevant factors. Specifically, the study focuses on the non-accounting students' perceptions to learn accounting courses online relative to their respective academic disciplines. When Covid-19 hit Malaysia in 2020, online learning continues to take place to replace the face-to-face classroom. The Higher Education Ministry has announced that all teaching and learning activities to be conducted through online platforms until 31 December 2020. The process seems simple, but the challenge of educating remains, not just for the instructors, students but also among parents. Thus, the study addresses the following two general research questions:

RQ 1: How do non-accounting students perceive to learn accounting courses on digital platforms?

RQ 2: What is the most influential factor that can influence the non-accounting students to learn accounting courses on digital platforms?

\section{Literature Review}

Electronic learning or commonly referred to as online learning has been around since 1999 (Hussin, Bunyarit \& Hussein, 2009). In step with Marianne, Linda, Yukie, and Austin (2012), the term online learning can be used to refer to a wide range of programs that use the web to supply instructional materials and facilitate interactions between teachers and students and in some cases among students as well. Previous authors (Sujit, Marguerite \& Paul, 2018; Agung \& Ramdani, 2019; Rao, 2011) may refer the term online learning as digital learning, virtual learning, or visual learning synonymously and interchangeably to bring the meaning of any kind of learning that features using digital technology.

The teaching and learning activities are not limited to the traditional model where the instructors focus this activity within the classroom rather it should be in line with the present development of information technology facilities. Online learning is one of the examples of using information and communication technology to facilitate the learning and teaching process (Chear, 2017; Nordin \& Singh, 2018). Games, videos, slideshows, video conferencing, and live discussions are all parts of online learning tools utilized by the instructors during online classes. Moreover, the way of learning has changed with the event of technology. In reality, the majority of students nowadays are from Generation Z or Gen Z which they are more likely to depend on the utilization of technology in their daily activities and inseparable from the technology. Therefore, an appropriate shift needed to be done in the teaching and learning process to be in line with technological developments.

The characteristics of online learning have changed to be in line with technology advancement. Two categories of technology application can be employed in teaching and learning activities, namely synchronous and asynchronous. The first application involves technology platforms that can be used in real-time such as Skype, Google Hangout, Google Meet, YouTube Live, Zoom Meeting, and Facebook Live. The instructors can conduct their classes as usual without having to assemble in the classroom or lecture hall. During MCO, these platforms were widely used to lower the risk of Covid19 infection. On the other hand, LMS, e-bulletin boards, emails, social media platforms, and learning videos are among examples of technology that may be used asynchronously. This application allows teaching and learning activities to take place without requiring the instructors and students to be 
INTERNATIONAL JOURNAL OF ACADEMIC RESEARCH IN BUSINESS AND SOCIAL SCIENCES Vol. 10, No. 8, 2020, E-ISSN: 2222-6990 @ 2020 HRMARS

present at the same time. LMS allows the institutions to manage contents, record lectures, store learning materials, and communicate with students (Ninoriya, 2011).

Communication in conventional learning is commonly cited as one-way and teacher-centered where students interact directly if they have any doubts about what is being taught (Shahaimi \& Khalid, 2016). Online interaction on the other hand can open up greater space and opportunities for the students to interact in the discussion. A study by Zaidatun and Yap (2000) shows that the use of interactive multimedia materials can make learning easier and understandable. Students are more inquisitive about the new technology and willing to use it for online learning. Zazaleena, Nursyahidah, Mohd Norafizal, and Nor Zalina (2012) found that the acceptance level of the students in using online learning for teaching and learning activities is high if it can provide the identical learning experience as the current education style and able to provide an interactive learning environment. The success of an online course depends on effective course design employing a student-centered model, delivery, and assessment (Mortagy \& Bonghikian-Whitby, 2010).

In another study conducted by Donnie, Bambang, Ahmed, and Syafika (2018), students have a rather positive perception towards online learning and that they were ready for blended learning. On top of that, students were no longer relying upon their instructors to provide the educational materials. The instructors should not just deliver their syllabus but should be more to encourage the students' participation in the online discussion and communicate with one another. The encouragement and motivation from the instructors to have interaction in the usage of online learning are important because students nowadays used mobile technology extensively but they were unacquainted with online learning tools (Ngampornchai \& Adams, 2016). In another study done by Husam and Selieman (2009), students' prior experience in using computers may influence their perceived skills and perceptions towards using computers for learning purposes. Findings from Selvi (2010) showed that the instructors' competencies, participants' attention, online learning environment, and time management contribute to the students' motivation in the online course. In a nutshell, online learning incorporates a positive influence and a positive impact on students' performance with a much better understanding of their registered courses (Mahajan \& Kalpana, 2018).

A study conducted by Patricia, Gilvania, Neilson, and Pamella (2015) suggested that students in Business Administration, Economics, and Accounting majors had positive initial perceptions of introductory accounting classes. In a very comparison of the first two majors, accounting students' majors were the foremost optimistic since the accounting classes were more relevant to their academic and professional performance. Azleen, Mohd Rushdan, Rahida, and Mohd Zulkeflee (2009) in their findings revealed that accounting experiences students perceived more confident in taking the accounting course compared to non-accounting experience student. Similar findings were discussed in Tickell, Tiong, and Balasinghan (2012) where the accounting major students hold significantly more positive attitudes to the first course in accounting than does business major students. This finding supports that of Geiger and Ogilby (2000) who find that students majoring in accounting have a more favorable perception of the introductory accounting course than do other students. 
INTERNATIONAL JOURNAL OF ACADEMIC RESEARCH IN BUSINESS AND SOCIAL SCIENCES Vol. 10, No. 8, 2020, E-ISSN: 2222-6990 @ 2020 HRMARS

The role of the instructor was perceived as very significant in making the course easily understood and enjoyable (Gois \& Bras, 2013). Students' perception of accounting course highly depending on how the instructor influence the student's opinion on the usefulness of the course. Similar findings were mentioned in Azmi, Zam, and Zulkarnain (2010), where the role of instructors was a key factor to influence the students' results, particularly for accounting courses. Besides, the accuracy in answering the questions also contributes to the students' performance in accounting courses. However, non-accounting students may perceive differently (Moriza, Wan Mustaffa, Zia, 2017). Accounting courses were perceived as a difficult course which is hard to learn as if learning a brandnew language. As a result, it creates anxiety among the students. This could be explained that interest maybe a drive or a person's tendency to relinquish attention to something, someone, or activity. Interactive learning sessions must be conducted and also the instructors should concern whether the non-accounting students feel that the accounting course is hard, burden, and uninteresting.

Online learning might not be appropriate for each student. There are two main challenges for instructors to conduct online classes, namely internet accessibility (Amiruddin \& Khaizer, 2019; Norazlin \& Rahaimah, 2019) and stability of teaching platforms. Internet accessibility becomes one in all the important criteria for conducting online classes. The instructors work out suitable teaching and learning platforms by identifying the amount of the internet accessibility whether low, medium, or high for every student so the online classes may be conducted smoothly. Students living in rural areas with poor internet coverage must be reached through more suitable platforms like WhatsApp, Telegram, Instagram, and Messenger applications. This can be important to prevent students from leaving behind and at the same time to stimulate students' cognitive systems continuously. For students that have medium access to the internet, platforms like YouTube and Kahoot are most fitted to use while for students who have a good internet connection, face to face platforms like Zoom, Microsoft Team, Skype and Google Meet are suitable to be used.

Nevertheless, the responsibility to facilitate the migration process from traditional mode to online teaching and learning activities falls on the shoulders of both parties, namely the instructors and students. Online learning unveils new opportunities for all higher educations in the effort to remodel the education sectors into digitalization in line with the IR 4.0 and the education blueprint. Furthermore, this can be certainly the safest method to interchange face to face interactions within the classrooms during the implementation of the MCO to interrupt the Covid-19 epidemic chain.

\section{Research Methodology}

The primary data collection process was carried out in Faculty of Business and Accountancy, at a private Malaysian university using a structured survey questionnaire which was designed and tailored to academic settings (Bibiana Lim, Hong \& Tan, 2008; Songsangyos, Kankaew \& Jongsawat, 2016; Winarto, Panjaitan \& Tambunan, 2019; Sumarni \& Zamri, 2018). The survey form consists of Section A (demographic information) and Section B (non-accounting undergraduate students' acceptance towards learning accounting courses on digital platforms). Data for Section B were gathered using five-point Likert type scales ranging from 1 (strongly disagree) to 5 (strongly agree), consists of 32 items assessed from four dimensions namely; learner characteristics, technology and system, interactive application, and instructor characteristics. 
INTERNATIONAL JOURNAL OF ACADEMIC RESEARCH IN BUSINESS AND SOCIAL SCIENCES Vol. 10, No. 8, 2020, E-ISSN: 2222-6990 @ 2020 HRMARS

The questionnaires were distributed to all non-accounting undergraduate students who were enrolled in two accounting courses; Principles of Accounting and Managerial Accounting in semester April 2020 using the web-based survey tool, Google Form. These two courses are among compulsory courses for the non-accounting undergraduate students to be able to graduate from their programme. In all, 130 non-accounting undergraduate students had participated in the study and after going over the respondents' data, all data were usable for further analysis, giving a usable rate of $67 \%$. Descriptive statistics and statistical inference were used to analyse the mean, standard deviation, frequency, and percentage using the Statistical Package for Social Sciences (SPSS) version 25.0. The results were based on the total number of respondents answering each particular question.

\section{Findings and Discussion}

The section presents the results for the questions associated with the level of acceptance of nonaccounting students towards learning accounting courses on digital platforms. Descriptive characteristics of the profile of the respondents from the survey were illustrated in Table 2 . Female respondents outnumber male respondents, accounting for 86 (66.2\%) as against 44 (33.8\%), respectively as expected from previous studies (Yong, 2017; Suppiah, Velayudhan \& Hari, 2012; Latifah, 2015). The majority of the respondents were from the age group of 21 to 23 years (65.4\%) and 24 to 25 years (26.2\%), 8.5 percent were from the 18 to 20 years' group. In terms of programme enrolled, most of the respondents were from Bachelor of Business Management (33.8\%), followed by Bachelor of Human Resource Management (25.4\%), Bachelor of Finance (20\%), Bachelor of Business Administration (18.5\%), and Bachelor of Industrial Management (2.3\%).

Table 2: Demographic Information of the Respondents

\begin{tabular}{llll}
\hline Item & Variables & $\mathbf{N}=\mathbf{1 3 0}$ & Percentage (\%) \\
\hline Age & 18-20 years' old & 11 & 8.5 \\
& 21-23 years' old & 85 & 65.4 \\
& 24-26 years' old & 34 & 26.2 \\
\hline Gender & Female & 86 & 66.2 \\
& Male & 44 & 33.8 \\
\hline Programme & Bachelor of Business Administration & 24 & 18.5 \\
& Bachelor of Business Management & 44 & 33.8 \\
& Bachelor of Finance & 26 & 20.0 \\
& Bachelor of Human Resource Management & 33 & 25.4 \\
& Bachelor of Industrial Management & 3 & 2.3 \\
\hline Preferred & Google Classroom & 21 & 16.2 \\
Online & Google Meet & 53 & 40.8 \\
Learning & Hangouts & 10 & 7.7 \\
Platform & OWC & 41 & 31.5 \\
& Skype & 5 & 3.8 \\
\hline Accounting & Yes & 100 & 76.9 \\
knowledge & No & 30 & 23.1 \\
\hline
\end{tabular}

Table 2 further indicates that the majority of the respondents preferred Google Meet (40.8\%) as their online learning platform. Since Google Meet is free for everyone and simply accessible from 
INTERNATIONAL JOURNAL OF ACADEMIC RESEARCH IN BUSINESS AND SOCIAL SCIENCES Vol. 10, No. 8, 2020, E-ISSN: 2222-6990 @ 2020 HRMARS

anywhere, it is the foremost preferred online learning platform by students and lecturers. Meanwhile, OWC (31.5\%) is an online web conferencing and learning platform provided by the private university, and also the majority of the courses were delivered through this platform. Apart from these two online learning platforms, other platforms were Google Classroom (16.2\%), Hangouts (7.7\%), and Skype (3.8\%). Based on the sample criterion set in this study, the majority of the respondents (76.9\%) have accounting knowledge, probably from the Diploma programme and only 30 respondents $(23.1 \%)$ did not have any prior accounting knowledge.

The level of non-accounting students' acceptance and willingness to learn accounting courses on digital platforms were discussed supported the frequency, percentage, and mean. The mean score interpretation was taken from five values points which is that the highest value of 5.00 divided into three levels, namely low (mean $=1.00-2.49)$, moderate (mean $=2.50-3.49)$, and high $(\operatorname{mean}=3.50$ - 5.00). Table 3 below shows the interpretation of the mean employed in Jamil (2002) and Wiersma (2000) in their studies.

Table 3: Mean Score Interpretation

\begin{tabular}{ll}
\hline Mean Score & Interpretation \\
\hline $1.00-2.49$ & Low \\
$2.50-3.49$ & Moderate \\
$3.50-5.00$ & High \\
\hline
\end{tabular}

Table 4 below shows the mean scores for the four contributing factors towards the acceptance of the non-accounting students to learn accounting courses through digital platforms. From the descriptive statistics, it showed that among the items from the four factors, students are more preferred to learn accounting courses in the classroom (mean $=4.25$ ). Most of the students agreed that they furnish careful attention to the instructors in the classroom. The result shows that students have difficulty in learning accounting courses (mean $=3.06$ ) on digital platforms. They find it difficult to understand certain accounting topics though many of them have basic accounting knowledge (mean $=3.42$ ) and have confidence and motivation (mean $=3.48$ ) in learning accounting courses online (mean = 3.36). Nevertheless, they are willing to participate and involve (mean $=3.65$ ) in online learning activities.

The findings also show that the online learning system allows easy access to information (mean = 3.61), hence the coursework such as quizzes, tests, tutorials, and assignments is uploaded easily to the LMS (mean = 3.68). Many of them also agreed that there is an interaction between instructors and students on digital platforms. They believe that having online discussion enables students to ask questions and exchange ideas between one another (mean = 3.53). However, many of the students also agreed that the online learning system did not provide interactive applications (mean $=3.43$ ), the design was not appropriate (mean $=3.45$ ) and the guidance screen was not clear and difficult to use (mean $=3.29$ ). Sometimes, they were disconnected during the online classes (mean $=3.30$ ) and the browsing speed was low (mean $=3.24$ ). The instructors also did not provide relevant learning content associated with the course (mean $=3.34$ ). 
INTERNATIONAL JOURNAL OF ACADEMIC RESEARCH IN BUSINESS AND SOCIAL SCIENCES Vol. 10, No. 8, 2020, E-ISSN: 2222-6990 @ 2020 HRMARS

Table 4: Mean Value of Non-Accounting Students' Acceptance Level towards Learning Accounting Courses on Digital Platforms

\begin{tabular}{|c|c|c|c|c|c|}
\hline & Statement & SD & Mean & Level & Rank \\
\hline \multirow{8}{*}{ 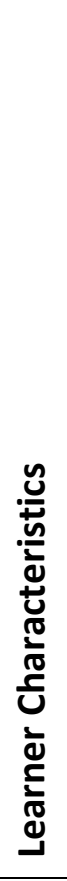 } & $\begin{array}{l}\text { I prefer to learn accounting in a lecture-based } \\
\text { classroom. }\end{array}$ & 0.750 & 4.25 & High & 1 \\
\hline & $\begin{array}{l}\text { I am willing to participate in online learning } \\
\text { activities. }\end{array}$ & 0.987 & 3.65 & High & 2 \\
\hline & $\begin{array}{l}\text { I believe in my capability to learn the courses with } \\
\text { technology. }\end{array}$ & 1.029 & 3.62 & High & 3 \\
\hline & $\begin{array}{l}\text { I have the initiative and motivation to learn } \\
\text { accounting courses and use the system. }\end{array}$ & 1.043 & 3.48 & Moderate & 4 \\
\hline & $\begin{array}{l}\text { I am cognitively engaged in doing online learning } \\
\text { activities. }\end{array}$ & 0.908 & 3.47 & Moderate & 5 \\
\hline & $\begin{array}{l}\text { I do have basic calculation skills to learn } \\
\text { accounting courses using an online learning } \\
\text { system. }\end{array}$ & 1.085 & 3.42 & Moderate & 6 \\
\hline & $\begin{array}{l}\text { I have a high level of self-confidence in learning } \\
\text { accounting courses using the system. }\end{array}$ & 1.194 & 3.36 & Moderate & 7 \\
\hline & $\begin{array}{l}\text { I would find learning accounting on online } \\
\text { learning is easy. }\end{array}$ & 1.262 & 3.06 & Moderate & 8 \\
\hline \multirow{8}{*}{ 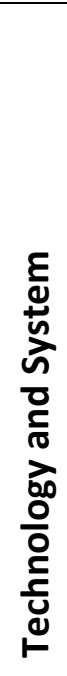 } & $\begin{array}{l}\text { The online learning system allows easy access to } \\
\text { information. }\end{array}$ & 1.089 & 3.61 & High & 1 \\
\hline & $\begin{array}{l}\text { The information from the online learning system } \\
\text { is up-to-date enough for my purposes. }\end{array}$ & 0.964 & 3.57 & High & 2 \\
\hline & The screen layout and design are appropriate. & 1.027 & 3.45 & Moderate & 3 \\
\hline & $\begin{array}{l}\text { The online learning system can provide learning } \\
\text { contents that are relevant to study accounting }\end{array}$ & 1.008 & 3.34 & Moderate & 4 \\
\hline & $\begin{array}{l}\text { I am rarely disconnected during the online } \\
\text { tutorial. }\end{array}$ & 1.111 & 3.30 & Moderate & 5 \\
\hline & The guidance screen is clear and easy to use. & 1.060 & 3.29 & Moderate & 6 \\
\hline & $\begin{array}{l}\text { I am satisfied with the online learning system } \\
\text { functions. }\end{array}$ & 1.180 & 3.27 & Moderate & 7 \\
\hline & I am satisfied with the browsing speed. & 1.126 & 3.24 & Moderate & 8 \\
\hline \multirow{5}{*}{ 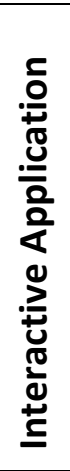 } & $\begin{array}{l}\text { Uploading my coursework to the online learning } \\
\text { system is easy. }\end{array}$ & 0.898 & 3.68 & High & 1 \\
\hline & I can ask questions and receive answers. & 0.951 & 3.62 & High & 2 \\
\hline & $\begin{array}{l}\text { I think sharing knowledge through online } \\
\text { discussions is time-consuming }\end{array}$ & 0.963 & 3.58 & High & 3 \\
\hline & $\begin{array}{l}\text { Online discussion enables students to exchange } \\
\text { ideas and comments. }\end{array}$ & 1.051 & 3.53 & High & 4 \\
\hline & $\begin{array}{l}\text { I benefit from using online interactive } \\
\text { applications. }\end{array}$ & 1.019 & 3.43 & Moderate & 5 \\
\hline
\end{tabular}


INTERNATIONAL JOURNAL OF ACADEMIC RESEARCH IN BUSINESS AND SOCIAL SCIENCES Vol. 10, No. 8, 2020, E-ISSN: 2222-6990 @ 2020 HRMARS

The online learning system provides an attractive learning environment

My interaction with the online learning system is clear and understandable.

I can concentrate on the quality of learning accounting courses using the online learning system.

The instructor encourages student interactions.

The instructor's knowledge of using Internet technology affects the efficiency of online learning.

The instructor is enthusiastic about teaching and explaining via the web.

The instructor is easily contacted.

The instructor provides fast feedbacks to queries in the discussion forum.

The instructor solves emerging problems efficiently.

The instructor provides sufficient learning resources online.

The instructor explains how to use the website at the beginning of the semester.
$1.077 \quad 3.42 \quad$ Moderate 6

$1.158 \quad 3.24 \quad$ Moderate 7

$1.131 \quad 3.23 \quad$ Moderate 8

$\begin{array}{llll}0.887 & 3.79 & \text { High } & 1\end{array}$

$\begin{array}{llll}0.817 & 3.75 \text { High } 2\end{array}$

$0.898 \quad 3.68$ High 3

$\begin{array}{llll}0.857 & 3.67 & \text { High } & 4\end{array}$

$0.793 \quad 3.66$ High 5

$\begin{array}{llll}0.843 & 3.65 \text { High } & 6\end{array}$

$\begin{array}{llll}0.923 & 3.57 & \text { High } & 7\end{array}$

$0.942 \quad 3.53 \quad$ High $\quad 8$

From the table above, it can be seen that the instructor characteristics are the foremost influential factor for the students to be motivated and participate in online learning activities. All eight items in the variable score mean above 3.50 which may be interpreted as high. The majority of the students agreed that the role of the instructors to encourage the students' interaction in online learning activities is vital (mean $=3.79$ ). The instructors must know using internet technology to ensure the efficiency of online learning (mean $=3.75$ ) must be enthusiastic and motivated to teach online classes (mean = 3.68). The finding from the study is consistent with Abidin (2014) where the role of the instructors to obtain digital literacy skills was considered very significant in ensuring the success of the online classes. Digital literacy is constructed based on three principles (Suleiman, 2012); knowledge and skills, ability to understand the content and its application, and skill to use digital technology.

The role of instructors in the era of IR 4.0 is not only to disseminate knowledge but to educate and guide the students into resilient, flexible, lifelong learning, critical thinking, and creativity. They ought to not only impart information and knowledge to the students but also encourage them to participate in the online discussions. During online classes, the instructors must be easily contacted (mean = 3.67), provide fast feedbacks (mean $=3.66$ ), and supply sufficient learning resources (mean $=3.57$ ). On top of that, the instructors must enlighten the students on how to use digital platforms at the beginning of the semester. The instructors themselves must make sure that they can apply the technology in their teaching and learning process so that they can guide the students and manage 
INTERNATIONAL JOURNAL OF ACADEMIC RESEARCH IN BUSINESS AND SOCIAL SCIENCES Vol. 10, No. 8, 2020, E-ISSN: 2222-6990 @ 2020 HRMARS

the online learning effectively. Chew (2015) suggested that the instructor must upgrade their ability to structure their teaching and apply it when designing the learning activities.

Table 5 below shows the overall means of the four contributing factors towards the acceptance level of the non-accounting students to learn accounting courses on digital platforms. From the table, it can be concluded that instructor characteristics (overall mean $=3.66$ ) are the foremost influential factor towards the non-accounting students' acceptance to learn accounting courses online. Additionally, learner characteristics also contribute to the high overall mean value (3.54) to the acceptance level. Interactive application and technology and also the system can be said moderately affect the acceptance level of the non-accounting students to learn accounting courses on digital platforms, which bring overall mean 3.48 and 3.38 respectively.

Table 5: Overall Mean Value of Non-Accounting Students' Acceptance of Learning Accounting Courses on Digital Platforms

\begin{tabular}{lllll}
\hline Variables & Overall SD & Overall Mean & Level & Rank \\
\hline Instructor Characteristics & 0.704 & 3.66 & High & 1 \\
Learner Characteristics & 0.780 & 3.54 & High & 2 \\
Interactive Applications & 0.839 & 3.48 & Moderate & 3 \\
Technology and System & 0.895 & 3.38 & Moderate & 4 \\
\hline
\end{tabular}

From the overall means above, the study found that learning accounting courses on digital platforms were perceived positively by non-accounting students. However, if the students were offered to learn accounting courses between the online-based classroom and physical classroom, they would value more highly to have the latter. It was found that the instructor characteristics could influence and motivate the students to learn accounting courses online. In today's environment, the role of the instructors can easily get replaced by artificial intelligence to carry out their tasks. Thus, an appropriate shift needed to be made in the process of delivering knowledge to be in line with technological developments. In all, it can be said that the instructor will continue to play a central role in education, as a learning catalyst and knowledge navigator for students participating in online education (Olson, 2005). Hence, for at least the following few years, the institutions need to come out with online learning tools, contents, and modules for better teaching and learning delivery to form a positive impact on the students' performance (Mahajan \& Kalpana, 2018).

On the other hand, students must arrange their learning schedule, and find the appropriate learning materials, be more active and independent. Basic skills in using computers are important to facilitate the employment of online learning. Yusri (2017) mentioned that it is important for a student to master the fundamental skills to use online learning well. Finding authentic and accurate learning materials is one of the lifelong learning skills that require to be developed by each student. In another study by Ismail \& Shelley (2008), as long as students have the appropriate skills to use online learning tools, they perceive online learning may be a useful and versatile way of learning, they felt motivated and enjoyed from online instruction. Students should bear in mind their responsibilities in ensuring the learning process continues, while there have been no physical classes. 
INTERNATIONAL JOURNAL OF ACADEMIC RESEARCH IN BUSINESS AND SOCIAL SCIENCES Vol. 10, No. 8, 2020, E-ISSN: 2222-6990 @ 2020 HRMARS

The Covid-19 crisis has brought major changes to the educational system in Malaysia. The impact can be seen where universities and colleges were forced to deliver their courses online. The adoption of online learning on various digital platforms has been unprecedented by many of the instructors still as students. On the other hand, the speed of the industrial revolutions has changed the patterns of teaching delivery and learning activities to be more digitally centered and become the norm.

\section{Conclusion}

In conclusion, the findings of the study showed a high level of acceptance among non-accounting undergraduate students to learn accounting courses on digital platforms. It was revealed that the instructor characteristics were the foremost significant influential factor for non-accounting students to be motivated to learn accounting courses online. A flexible way of learning, communicating, and sharing from online discussion and instruction leads to a high level of acceptance, engagement, and enjoyment in learning accounting courses. Besides, the learner characteristics of learning accounting courses are positive and favorable. The study revealed that the non-accounting undergraduate students felt confident and were keen and wanting to learn accounting courses online as long as the perceived skills to use the online tools were acquired. Learning accounting courses on digital platforms may be more easily accepted if it can provide the identical learning experience based on the traditional lecture-based classroom.

Although the present study drew a broader picture of the influential factors to the non-accounting students to learn accounting courses online than previous studies, due to a small number of participants, it is not possible to generalize the acceptance level of the non-accounting students to other universities due to different environments and situations. Based on the findings, some suggestions for future studies were proposed. The larger and more diverse sample size is necessary so that the data will be more applicable to the increasingly diverse student population in Malaysian universities and colleges. The statistical data could even be collected using qualitative approaches, as an example from the semi-structured interviews, to produce a deeper understanding of the nonaccounting students' perception towards learning accounting courses online. The relationship between the acceptance level with the non-accounting students' attitude and behavior could also be further investigated. Nevertheless, the implications of the study are crucial for instructors, practitioners, and institutions who are within the planning and are currently engaged in offering online learning courses.

This study contributes to understanding the influencing factors intention of non-accounting students to learn accounting courses online. To the best of our knowledge, this present study is that the first to examine the preferences for online learning environments in terms of learning accounting courses from the perspective of the non-accounting students. From an academic perspective, this paper adds a brand-new perspective to the literature about online learning. From a practitioner perspective, the findings show that the universities, particularly the instructors must also empower themselves to ensure the online learning sessions be conducted effectively. In practical terms, this study contributes to giving possible recommendations to the practitioners and institutions on how to carry out the online learning sessions more effectively within the universities. In short, the committed effort between students, instructors, and institutions is vital to ensure proper implementation and adaptation to the online learning environment system. 
INTERNATIONAL JOURNAL OF ACADEMIC RESEARCH IN BUSINESS AND SOCIAL SCIENCES Vol. 10, No. 8, 2020, E-ISSN: 2222-6990 @ 2020 HRMARS

\section{References}

Azleen, I., Rushdan, M. Y., Rahida, A. R., \& Zulkeflee, M. A. R. (2009). The Study of Students' Perception towards Principle of Accounting (PA): A Survey Among Business Students. International Journal of Business Education, 1, 52-65

Donnie, A., Bambang, S., Ahmed, M., \& Syafika, N. M. N. (2018). E-Learning Readiness Among Students of Diverse Backgrounds in a Leading Malaysian Higher Education Institution. Malaysian Journal of Learning and Instruction, 15(2), 227-256

Geiger, M. A., \& Ogilby, S. M. (2000). The first course in accounting: students' perceptions and their effect on the decision to major in accounting. Journal of Accounting Education, 18, 63-78.

Gois, C., \& Bras, F. A. (2013). In the aftermath of the Bologna process: exploring the master students' perceptions of accounting in two Portuguese higher education institutions. The Spanish Journal of Accounting, Finance and Management Education, 4, 34-35

Husam, A. A., \& Sulieman, A. B. (2009). Attitudes toward learning accounting by computers: The impact on perceived skills. Journal of Accounting and Taxation, 1(1), 001-007

Hussin, H., Bunyarit, F., \& Hussein, R. (2009). Instructional design and e-learning: Examining learners' perspectives in Malaysian institutions of higher learning. Campus-Wide Information System, 26(1), 4-19

Ismail, S., \& Kasim, N. (2011). Accounting for Non-Accounting Students: What Affects Their Performance? Journal of Technical Education and Training, 3(2)

Ismail, S., \& Shelley, M. C. (2008). Considering Students' Perceptions: The Distance Education Student Satisfaction Model. Educational Technology \& Society, 11(3), 216-223

Kauffman, H. (2015). A review of predictive factors of student success and satisfaction with online learning. Research in Learning Technology, 23

Krishnan, S. (2016). Students' Perceptions of Learning Mode in Mathematics. The Malaysian Online Journal of Educational Sciences, 4(2), 32-41

Mahajan, M. V., \& Kalpana, R. (2018). A study of students' perceptions of e-learning. Indian Journal of Clinical Anatomy and Physiology, 5(4), 501-507

Ministry of Education Malaysia. (2013). Malaysia Education Blueprint 2013-2025. Retrieved

from https://www.moe.gov.my/index.php/en/dasar/pelan-pembangunan-pendidikan Malaysia2013-2025

Azmi, M. N. A., Zam, N. W., \& Zulkarnain, S. I. (2010). Pandangan Pelajar Terhadap Matapelajaran Prinsip Perakaunan di Daerah Maran, Pahang.

Amiruddin, M. A. D., \& Khaizer, M. O. (2019). Meneroka Impak dan Cabaran Pensyarah Terhadap Pelaksanaan E-Pembelajaran di Kolej Vokasional Zon Tengah, Malaysia. The $5^{\text {th }}$ International Conference on Educational Research and Practice

Moriza, F., Mustaffa, W. Y., \& Zia UI Saufie, A. M. J. (2017). Penggunaan Prosedur "Smart Accounting" di KAlangan Pelajar-Pelajar Politeknik: Satu Kajian Kes. Advanced Journal of Technical and Vocational Education, 1(1), 301-308

Mortagy, Y., \& Bonghikian-Whitby, S. (2010). A Longitudinal Comparative Study of Student Perceptions in Online Education. Interdisciplinary Journal of E-Learning and Learning Objects, 6, 23-44

Ngampornchai, A., \& Adams, J. (2016). Students' acceptance and readiness for E-learning in Northeastern Thailand. International Journal of Educational Technology in Higher Education, 13(34) 
INTERNATIONAL JOURNAL OF ACADEMIC RESEARCH IN BUSINESS AND SOCIAL SCIENCES

Vol. 10, No. 8, 2020, E-ISSN: 2222-6990 @ 2020 HRMARS

Norazlin, M. R., \& Rahaimah, S. A. (2019). Amalan dan Cabaran Pelaksanaan Pembelajaran Abad ke 21. Proceedings of the International Conference on Islamic Civilisation and Technology Management, 23-24 November 2019

Olson, P. W. (2005). Significant Success Factors in Distance Education. International Journal of Case Method Research \& Application, 11(2), 235-245

Patricia, S. C., Gilvania, S. G., Neilson, R., \& Pamella, P. B. (2015). An Analysis of Student Perceptions of Introductory Accounting Classes. International Journal of Advances in Management and Economics, 4(4), 39-56

Chew, R. S. Y. (2015). Perceptions of Online Learning at an Australian University: Malaysian Students' Perspective - Learning Support. International Journal of Information and Education Technology, 5(8), 587-592

Said, M. H., \& Mohd Tahir, L. (2013). Towards Identification of Students' Holistic Learning Process through Facebook in Higher Education. Procedia-Social and Behavioral Sciences, 97, 307-313.

Salwa, M., Hanum, A. H., Haslin, J., Jamil, M. S., \& Nurizzah, J. (2013). The Key Contributing Factors of Non-Accounting Students' Failure in The Introduction to Financial Accounting Course. Procedia - Social and Behavioural Sciences, 90, 712-719

Selvi, K. (2010). Motivating factors in online courses. Procedia Social and Behavioral Sciences, 2, 819824

Tichavsky, L. P., Hunt, A. N., Driscoll, A., \& Jicha, K. (2015). "It's Just Nice Having a Real Teacher": Student Perceptions of Online versus Face to Face Instructions. International Journal for the Scholarship of Teaching and Learning., 9(2)

Tickell, G., Tiong, K. L., \& Balasinghan, B. (2012). Student Perceptions of the First Course in Accounting: Major Versus Non-Majors. American Journal of Business Education, 5(5), 501-514

Zazaleena, Z., Nursyahidah, A., Mohd Norafizal, A. A., \& Nor Zalina, I. (2012). E-Learning Awareness in a Higher Learning Institution in Malaysia. Social and Behavioural Sciences, 67, 621-625. 